\title{
PALEOMAGNETISM OF THE DIKE SYSTEMS IN FINLAND V. REMANENT MAGNETIZATION OF THE ÅA INTRUSIVES
}

\author{
K. J. Neuvonen \\ Institute of Geology, University of Turku, Finland
}

ABSTRACT

The direction and strength of remanent magnetization were measured for different intrusive rocks of the Precambrian Ava ring intrusion. Two nearly opposite directions were revealed after demagnetization, both in agreement with earlier measurements in SW-Finland. The pole sites are compared with those measured in Sweden. The pole wandering curve and the reversal periods are considered as tools in the Precambrian stratigraphy.

\section{Introduction}

The ring structure of Ava lies in the northeastern corner of the Aland islands (Fig. 1). The circular intrusions and associated dike rocks are described and discussed by Sederholm (1924 and 1934) and in more detail by Kaitaro (1953). According to Kaitaro, the intrusions can be divided into the following types:

1. monzonites

2. coarse grained granites

(central stock and inner ring intrusions)

3. fine grained granites (outer ring intrusions)

4. pegmatite and aplite dikes

5. lamprophyric dikes (radiating dikes)

6. diabase and quartz-porphyry dikes (radiating and transecting dikes)

The monzonites and granites contain magnetite in abundance and the complex is clearly visible on the aeromagnetic map published by the Geological Survey of Finland, sheet 1041, Iniö.

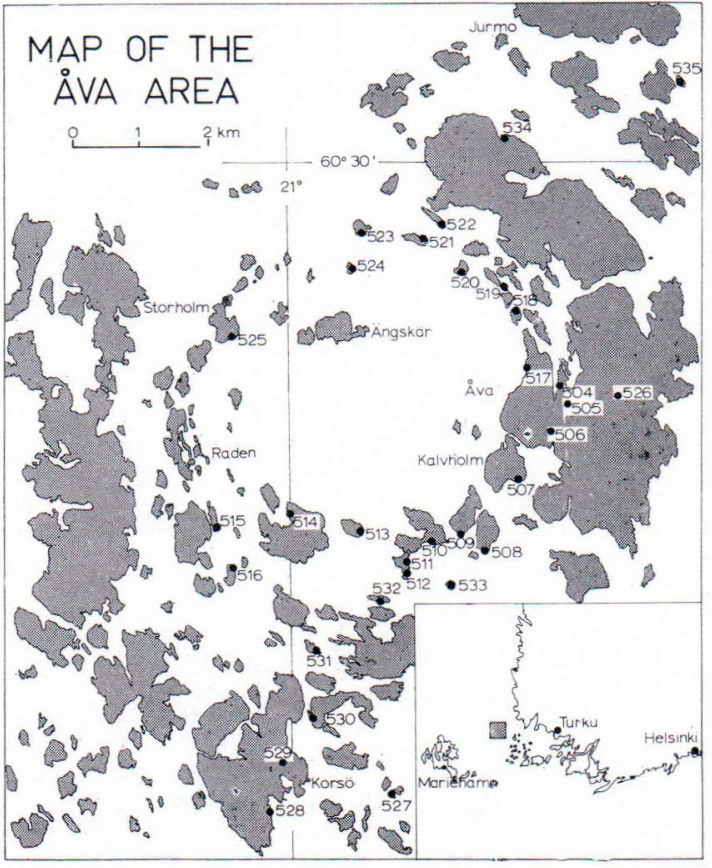

Fig. 1. Location of the Ava area and the sampling sites. 
The petrology of the different rock types is described by Kaitaro (1953) and is omitted here. The monzonites are, according to Kaitaro, slightly older than the granites. Lamprophyre dikes transect the major intrusives but their shape indicates intrusion before the final consolidation of the granite. Most of the diabase dikes in the Ava area are narrow and fine grained. They follow the radiating joint lines of the structure and, consequently, belong to the main intrusion sequence. The diabase encountered at Korsö, on the other hand, is very coarse grained and has a width of more than 300 meters. Its age relation to the ring intrusion is unknown.

The radiometric age of the Âva intrusions is not directly known ${ }^{1}$. Lokka (1950) determined the age of an allanite sample from $\AA$ va granite pegmatite by means of the chemically analyzed $\mathrm{Pb} / \mathrm{U}$ ratio to be about $1116 \mathrm{~m}$.y. but this value must be considered as far too low. Sederholm (1934) regarded Ava granite as Archean and classified it together with the similar coarse grained and undeformed granites in Bodom, Onas, Obbnäs etc. all occuring in southern Finland. These intrusions formed the so called third granite group of Sederholm. Eskola (1946) considered the Ava granite and the other granites of the third group as postkinematic intrusions of Svecofennian orogenesis. Kouvo (1958) determined the zircon isotope ages of Bodom and Onas granites. Both determinations fit on the same discordia curve in the $\mathrm{Pb}^{206} / \mathrm{U}^{238}$ $\mathrm{Pb}^{207} / \mathrm{U}^{235}$ diagram, yielding an age of $1690 \pm 10$ m.y. as an intersection with the concordia curve. Three isotope determinations, which Kouvo made on rapakivi zircons, also lie on the same discordia line. This indicates that the intrusions of the third group must be of the same age as rapakivi, i.e. also the Ava intrusions are about 1670-1700 m.y. old. ${ }^{1}$

\section{Samples and the magnetic stability}

For the paleomagnetic investigation 53 oriented vertical core samples were drilled on 32 1) See Addendum sites in the area (Fig. 1). These samples include monzonites, fine and coarse granites, diabase, lamprophyre and quartz porphyry dikes. The fine grained outer ring granites and the quartz porphyry dike samples turned out, however, to be so weakly magnetized that they could not be measured with the magnetometer available and had to be omitted.

The direction and strength of the remanent magnetization were determined on cylindrical specimens $(\varnothing=25 \mathrm{~mm}, \mathrm{~h}=20 \mathrm{~mm})$ as an average of 24 measurements with a four probe fluxgate magnetometer (Förster-Oerstedmeter). A magnetic cleaning was performed at $350-500$ Oersteds peak field after runs of several pilot samples. The instrumentation used was principally the same as that of Creer (1959) and described in Neuvonen (1965). Summary and statistic of the measurements before and after demagnetization are given in Tables 1 and 2, respectively. More diabase and lamprophyre samples would have been desired but suitable locations for sample drilling were not available because of the intensive fracturing of these rocks.

The magnetic stability of all the samples collected turned out to be quite poor. One component of the magnetization in the samples was, evidently, sufficiently stable, but there was another component which was soft and easily reoriented making the "cleaning out» of the specimens difficult. Consequently, the spread of the magnetic directions is larger after the demagnetization than before it. Attempts were made to improve the AC-demagnetization process used but without success. Temperature demagnetization was also tried with different types of heating arrangements, but without any improvement in the results. The small remainder in the compensated geomagnetic field (usually less than 20 gammas) was enough to reorient the magnetization direction of the specimens. This was revealed by the dependence of the magnetic directions of the heated specimens upon the orientation of the specimens in the oven. 
TABLE 1.

Natural remanent magnetization of the Ava intrusives.

Monzonites 15 sites (24 samples, 183 specimens)

Decl. $=24^{\circ} \quad$ Intensitics $1.5-292.010^{-4} \mathrm{emu} / \mathrm{cm}^{3}$

Incl. $=+77^{\circ} \quad \alpha_{95}=15^{\circ} \quad \mathrm{N}=15 \quad \mathrm{R}=13.055 \quad \mathrm{k}=7.198$

Granites $\quad 7$ sites (10 samples, 71 specimens)

Decl. $=42^{\circ} \quad$ Intensities 0.4-70.6 $10^{-4} \mathrm{emu} / \mathrm{cm}^{3}$

Incl. $=+82^{\circ} \quad \alpha_{95}=15^{\circ} \quad \mathrm{N}=7 \quad \mathrm{R}=6.627 \quad \mathrm{k}=16.090$

Diabases $\quad 5$ sites ( 8 samples, 64 specimens)

Decl. $=83^{\circ} \quad$ Intensities $1.0-214.010^{-4} \mathrm{emu} / \mathrm{cm}^{3}$

Incl. $=+57^{\circ} \quad a_{95}=34^{\circ} \quad \mathrm{N}=5 \quad \mathrm{R}=4.343 \quad \mathrm{k}=6.088$

Lamprophyres 2 sites (4 samples, 25 specimens)

Decl. $=109^{\circ} \quad$ Intensities $6.3-21.510^{-4} \mathrm{emu} / \mathrm{cm}^{3}$

Incl. $=+40^{\circ} \quad \mathrm{N}=2 \quad \mathrm{R}=1.775 \quad \mathrm{k}=4.452$

$\mathrm{N}=$ number of sites combined, $\alpha_{95}=$ semiangle of the cone of $95 \%$ confidence for the directions, $\mathrm{R}=$ length of the resultant of the $\mathrm{N}$ unit vectors, $\mathrm{k}=$ estimate of the precision parameter $(\mathrm{N}-1) /(\mathrm{N}-\mathrm{R})$.

TABLE 2.

Remanent magnetization of the $\AA$ va intrusives after A.C. demagnetization at 350-500 Oe.

Monzonites

Decl. $=33^{\circ} \quad$ Intensities $2.8-12.410^{-5} \mathrm{emu} / \mathrm{cm}^{3}$

Incl. $=+46^{\circ} \quad \alpha_{95}=19^{\circ} \quad \mathrm{N}=16 \quad \mathrm{R}=12.863 \quad \mathrm{k}=4.781$

Granites

Decl. $=65^{\circ} \quad$ Intensities $1.9-13.810^{-5} \mathrm{emu} / \mathrm{cm}^{3}$

Incl. $=+50^{\circ} \quad \alpha_{95}=33^{\circ} \quad \mathrm{N}=5 \quad \mathrm{R}=2.137 \quad \mathrm{k}=1.397$

Diabases

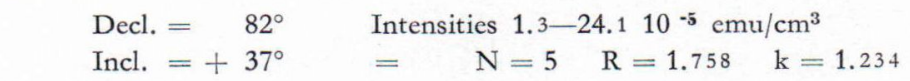

Lamprophyres

Decl. $=216^{\circ} \quad$ Intensities $1.0-7.210^{-5} \mathrm{emu} / \mathrm{cm}^{3}$

Incl. $=+50^{\circ} \quad \mathrm{N}=2 \quad \mathrm{R}=1.241 \quad \mathrm{k}=1.176$

Notations as in Table 1.

High requirements are needed for the demagnetization procedure and equipment since, as pointed out by Doell and Cox (1967), also an alternating field demagnetization might add a spurious component of magnetization to the specimen.
During the course of paleomagnetic investigations performed in Finland, the author has found (Neuvonen, 1969) that the stable magnetization of the magnetite bearing rocks seems to be limited to those in which a very fine grained ulvite-magnetite intergrowth occurs. This feature 
is most typical in the fast cooled volcanic and hypabyssal igneous rocks. In most plutonic rocks, the crystallization took place so slowly, that the ulvite-magnetite exsolution became too coarse to enable a single domain structure and the highest possible magnetic stability. This question requires further concideration and a $x$-ray study has been started.

In order to improve the reliability of the evaluted directions of magnetization, all the samples showing $\alpha_{95}$ larger than $25^{\circ}$ after demagnetization were rejected (Table 3 ). From the granite samples collected only one was stable enough to be included in Table 3 and all lamprophyre dikes had to be discarded. The remaining diabase dikes reveal two sets of very different (almost opposite) magnetic orientation.
Set 1 has a direction subparallel with the monzonites and can be included in the average direction with the monzonites and the granite (Table 4). The second set of magnetic orientation coincides with that observed for the Kumlinge diabase occuring just south of the Âva area $\left(\mathrm{D}=177^{\circ}, \mathrm{I}=+39^{\circ}\right.$, Neuvonen and Grundström, 1969). This direction is encountered in samples from the broad diabase dike at Korsö which is an occurence very different from the Ava diabases proper (see. p. 102). It is evident, consequently, that the Korsö diabase does not belong to the Ava intrusions but is of the same suite and age as the Kumlinge dikes. The magnetic direction measured on this rock can be combined and averaged with those obtained earlier for the Kumlinge dike set (Table 4).

TABle 3 .

Remanent magnetization of the Åva intrusives after A.C. demagnetization omitting all samples with $\alpha_{95}>25^{\circ}$.

Monzonites

Decl. $=26^{\circ}$

Incl. $=+31 \quad \alpha_{95}=17^{\circ} \quad \mathrm{N}=12 \quad \mathrm{R}=10.459 \quad \mathrm{k}=7.13^{\prime} \mathrm{y}$

Granites

$$
\begin{aligned}
& \text { Decl. }=20^{\circ} \\
& \text { Incl. }=+2^{\circ} \quad \mathrm{N}=1
\end{aligned}
$$

\section{Diabases}

1. set Decl. $=18^{\circ}$

Incl. $=+18^{\circ}$

2. set Decl. :- $188^{\circ}$

Incl. $=\div 24^{\circ}$

$$
\begin{array}{lll}
\mathrm{N}=2 & \mathrm{R}=1.814 & \mathrm{k}=5.377 \\
\mathrm{~N}=2 & \mathrm{R}=1.991 & \mathrm{k}=107.527
\end{array}
$$

TABLE 4.

Paleomagnetic pole positions calculated from the combined directions of magnetization.

Monzonites, granites and 1. set of diabase dikes

$$
\begin{aligned}
& \text { Decl. }=25^{\circ} \quad \alpha_{95}=15^{\circ} \quad \mathrm{N}=15 \quad \mathrm{R}=13.119 \quad \mathrm{k}=7.442 \\
& \text { Incl. }=+27^{\circ} \quad \text { Pole position Long. } 169^{\circ} \mathrm{E} \text {, Lat. } 41^{\circ} \mathrm{N} \\
& \delta \mathrm{p}=9^{\circ} \delta \mathrm{m}=17^{\circ}
\end{aligned}
$$

Diabase dikes, 2. set combined with Kumlinge diabase dikes (Neuvonen and Grundström, 1969):

$$
\begin{aligned}
& \text { Decl. }=181^{\circ} \quad a_{95}=17^{\circ} \quad \mathrm{N}=7 \quad \mathrm{R}=6.583 \quad \mathrm{k}=14.395 \\
& \text { Incl. }=+32^{\circ} \quad \text { Pole position Long. } 201^{\circ} \mathrm{E} \text {, Lat. } 13^{\circ} \mathrm{N} \\
& \text { (Reversed) } \delta \mathrm{p}=11^{\circ} \delta \mathrm{m}=19^{\circ}
\end{aligned}
$$




\section{Pole positions and discussion}

Table 4 also gives two paleomagnetic pole positions. One is calculated from the combined directions of magnetization of the Ava intrusives and another is calculated from those of the Kumlinge type diabase dikes. The sites are shown in Fig. 2 numbered 6 and 5, respectively. Calculations are based on the mean magnetic directions measured on demagnetized samples with $\alpha_{95}$ less than $25^{\circ}$. The pole positions are not very far from the sites calculated for the doleritic dike rocks in western and southwestern Finland by Neuvonen (1965 and 1966) and by Neuvonen and Grunström (1969). The Kumlinge diabases show reversed magnetization and the precision of the determination of this pole is somewhat improved when compared with the result obtained for it earlier.

The pole position 6 in Fig. 2 should represent the magnetic direction of the rapakivi intrusions. A great uncertainty, however, is involved in this determination because of the soft component of

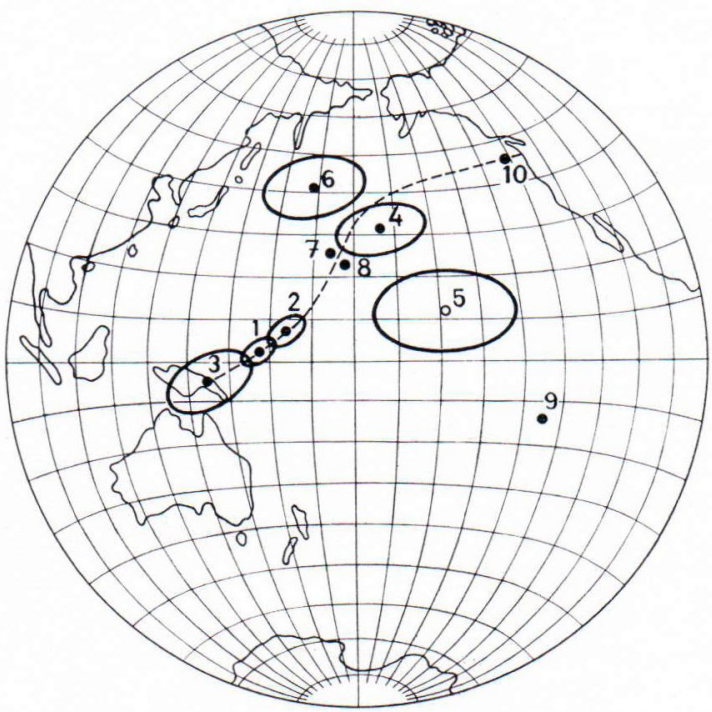

Fig. 2. Paleomagnetic pole positions. Finnish poles 1) Satakunta, 2) Vaasa, 3) Märket Jotnian dolerites. 4) Föglö, 5) Kumlinge, and 6) Åva sub-Jotnian intrusions. Swedish poles 7) Dala volcanics (sub-Jotnian), 8) Late Jotnian dolerites, and 9) Hyperite-dolerites (after Priem et. al., 1968). 10) Tärendö gabbro (Cornwell, 1968). All north poles (-) except 5) Kumlinge. magnetization present in the rocks measured. New attempts will, therefore, be taken to get more reliable results. The rapakivi pole site will be a very important milestone in establishing the pole wandering curve for future use in resolving the problems of Precambrian stratigraphy. Additional information is already available from Sweden.

Recently, Priem et. al. (1968) presented a large number of data concerning age and paleomagnetism of some Precambrian rocks in Sweden. The pole sites determined by Priem et. al. for subJotnian Dala volcanics and Late Jotnian dolerites are plotted in Fig. 2 (poles 7 and 8). They are both southwest but very close to pole $4 \mathrm{cal}$ culated for the Föglö diabase dikes (Neuvonen and Grunström, 1969). The pole determined by Priem for the Jotnian basalts (»Öje diabase») coincides with pole 4 in Fig. 2. Priem and his collaborators conclude that these rocks have undergone remagnetization in connection with the Caledonian disturbance, since the poles measured are situated amidst the Lower Paleozoic poles according to Irving (1964) and Storetvedt (1968). This explanation can hardly be valid for the Finnish sub-Jotnian and Jotnian pole positions and the idea of remagnetization has to be questioned. The existence of the reversed magnetization of Kumlinge diabases also makes the remagnetization hypothesis most unpropitious.

Welin et. al. (1966) reported a $\mathrm{Rb} / \mathrm{Sr}$ age of $1685 \mathrm{~m}$.y. for the sub-Jotnian volcanics from the Los Hamra region. This age is in excellent agreement with Kouvo's (loc. sit.) determination for rapakivi intrusions. Priem et al. (1968) give an age of 1405 m.y. for sub-Jotnian Dala volcanics and rapakivi type Garberg granite. The difference is great and unexplained even if the use of the different decay constants for ${ }^{87} \mathrm{Rb}$ are considered. The age and the pole positions obtained by Priem et al. for Jotnian basalt (»Öje diabase») and for Late Jotnian dolerites also differ notably from those given for the Finnish Jotnian dolerites (poles 1, 2 and 3 in Fig. 2). 
There might, however, be a quite marked age difference between these two rock units. Reliable radiometric ages are not available for any of these rocks.

The stable remanent magnetization found by Priem et al. (1968) in the hypetite dikes in southern Sweden points to a pole position about $15^{\circ} \mathrm{S}$, $135^{\circ} \mathrm{W}$ (pole 9 in Fig. 2). The $\mathrm{K}-\mathrm{Ar}$ age determinations of these rocks vary from 781 to 1573 m.y. These may be, as the authors state, moverprinted» ages. The same might be true also for the magnetic directions of these rocks.

Cornwell (1968) has determined the stable NRM and the pole position for a Precambrian (1 800-2000 m.y. old) Tärendö gabbro in northern Sweden (pole 10 in Fig. 2). This result is in full agreement with the remanent magnetization measured by Puranen (1960) for a gabbro in Ylivieska, Finland, of an apparently similar age.

A line drawn in Fig. 2 connecting the different pole sites represents a tentative and rough pole wandering curve for the Fennoscandian rocks from about $1900 \mathrm{~m}$.y. to $1300 \mathrm{~m}$.y. This curve and the adjacent pole positions differ greatly from those constructed on the basis of Precambrian rocks in central and western Europe (e.g. Irving, 1964). This could be explained by the great block movements between different parts of the continent. On the other hand, the shape of the curve is also different and dissimilar from those suggested for African and Canadian rocks by McElhinny et al. (1968). It is clear that differences of this type, real or unreal, limit the use of the pole wandering curve for statigraphic correlations. For global Precambrian use, therefore, a time scale might turn out to be more useful in which the normal and reversed geomagnetic periods are indicated. The successful application of such a diagram requires the existence of clear and well-defined periods of both types. It is unknown, at present, if this is the case or not.

\section{Addendum}

After the submission of this paper for publication Dr. Olavi Kouvo of the Geological Survey of Finland reported the following analytical results on minerals from the Âva monzonite and granite (Table 4, personal communication).

Samples were collected by Mr. Leif Bergman and disposed for analysis by Professor Nils Edelman of the Åbo Akademi.

When plotted on a concordia diagram (Fig. 3) together with some rapakivi zircons the results are not consistent with those obtained for rapakivi zircons. They suggest an age of about 1830 million years.

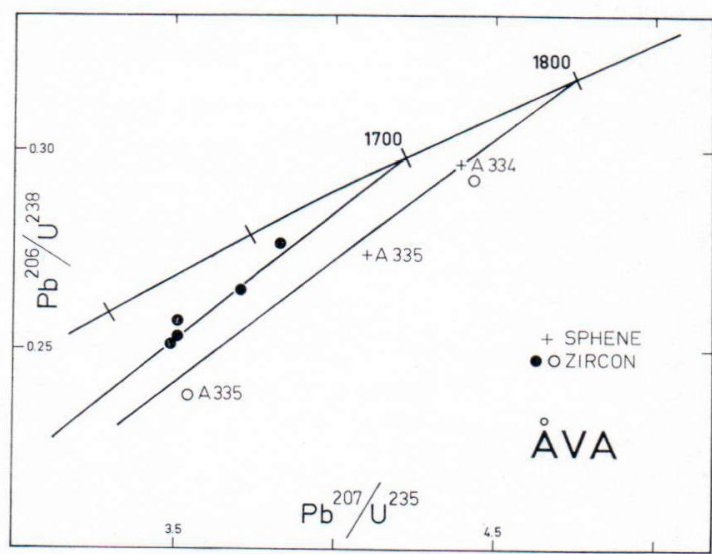

Fig. 3. Concordia diagram showing uranium-lead ratios for $\AA$ va zircons and sphenes, and for zircons from rapakivi, Onas granite and Bodom granite (solid circles). See also Kouvo (1958).

Acknowledgements - The author would like to express his thanks for all the assistance received in this work. Mrs. Ritva Ääri, Mr. Turkka Puisto, and Mr. Simo Marttila, B. Sc. helped in collecting, preparing and measuring the samples. Mrs. Tamara Kosonen made the drawings and Mrs. Gillian Häkli kindly corrected the English. Financial aid was given by the National Research Council for Science. 
TABLE 4

\begin{tabular}{|c|c|c|c|c|c|c|c|c|}
\hline \multirow{2}{*}{ Sample } & \multirow{2}{*}{ Rock and location } & \multirow{2}{*}{ Mineral } & \multirow{2}{*}{$\mathrm{U}, \mathrm{ppm}$} & \multirow{2}{*}{$\begin{array}{l}\text { Radiogenic } \\
{ }^{206} \mathrm{~Pb}, \mathrm{ppm}\end{array}$} & \multicolumn{4}{|c|}{$\begin{array}{l}\text { Isotopic abundance relative } \\
\text { to } 206 \mathrm{~Pb}\end{array}$} \\
\hline & & & & & 204 & 206 & 207 & 208 \\
\hline Ti-A334 & $\begin{array}{l}\text { Monzonite, Getören, } \\
\text { Åva, Brändö. }\end{array}$ & Sphene & 105 & 26.9 & 0.559 & 100 & 18.39 & 65.78 \\
\hline $\mathrm{Zr}-\mathrm{A} 334$ & 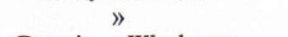 & Zircon & 218 & 55.0 & 0.2355 & 100 & 14.20 & 22.01 \\
\hline Ti-A335 & $\begin{array}{l}\text { Granite, W-shore } \\
\text { Ávalandet, Brändö. }\end{array}$ & Sphene & 92.3 & 21.73 & 1.016 & 100 & 24.76 & 103.72 \\
\hline $\mathrm{Zr}-\mathrm{A} 335$ & 》 & Zircon & 432 & 88.4 & 0.1620 & 100 & 12.99 & 21.17 \\
\hline
\end{tabular}

\section{REFERENCES}

Greer, K. M. (1959) A.C. demagnetization of unstable Triassic marls from S.W. England. Royal Astron. Soc., Geophys. Journ., Vol. 2, pp. 261-175.

Gornwell, J. D. (1968) The magnetization of PreCambrian rocks from the Tärendö district, Northern Sweden. Geol. Fören. Stockholm Förh. Vol. 90, pp. $529-536$.

Doell, R. R. and Cox, A. (1967) Analysis of alternating field demagnetization equipment. In Methods in Paleomagnetism, ed. Collinson, Greer, and Runcorn. Elsevier. Amsterdam-London-New York.

Eskola, Pentri (1946) Om Finlands graniter (A lecture with discussion). Geol. Fören. Stockholm Förh. Vol. 68, pp. $473-475$.

Irving, E. (1964) Paleomagnetism and its application to geological and geophysical problems. Wiley, New York.

Kaitaro, Simo (1953) Geological structure of the late Pre-Cambrian intrusives in the Åva area, Åland islands. Bull. Comm. géol. Finlande 162.

Kouvo, Olavi (1958) Radioactive age of some Finnish Pre-Cambrian minerals. Bull. Comm. géol. Finlande 182.

LoKKA, LAURI (1950) Contributions to the knowledge of the chemistry of the radioactive minerals of Finland. Bull. Comm. Finlande 149.

McElhinny, M. W., Briden, J. C., Jones, D. L., and Brock, A (1968) Geological and geophysical implications of paleomagnetic results from Africa. Rewiew of Geophysics, Vol. 6, pp. 201-238.
Neuvonen, K. J. (1965) Paleomagnetism of the dike systems in Finland I. Remanent magnetization of Jotnian dolerites in southwestern Finland. Compt. Rend. Soc. géol. Finlande, Vol. 37, pp. 153-168.

- (1969) Paleomagneettisen tutkimuksen nykytilasta. Geologi 3-4, pp. 33-34.

- and Grundström, Leo (1969) Paleomagnetism of the dike systems in Finland IV. Remanent magnetization of the dolorite and related dikes in the Aland archipelago. Bull Geol. Soc. Finland 41, pp. 57-63.

Priem, H. N. A., Mulder, F. G., Boelrijk, N. A. I. M., Hebeda, E. H., Verschure, R. H., and Verdurmen, E. A. Tн. (1968) Geochronological and paleomagnetic reconnaissance survey in parts of Central and Southern Sweden. Phys. Earth Planet. Interiors Vol. 1, pp. 372 380.

Puranen, M. (1960) Kivinäytteiden magneettisten ominaisuuksien tutkimusmenetelmistä. Geological Survey of Finland. Geoteknillisiä julkaisuja 64, pp. 32-42.

Sederholm, J. J. (1924) Granit-gneissproblemen belysta genom iakttagelser i Åbo-Ålands skärgård I. Geol. Fören. Stockholm Förh. 46, pp. 129-153.

- (1934) On migmatites and associated Pre-Cambrian rocks of southwestern Finland III. The Aland islands. Bull. Comm. géol. Finlande 107.

Storetvedt, K. M. (1968) A synthesis of the paleozoic paleomagnetic data for Europe. Earth and Planetary Science Letters, Vol. 3, pp. 444-448.

Welin, Eric, Blomqvist, Göran, and Parwell, AlexANDER (1966) Rb/Sr whole rock age data on some Swedish Precambrian rocks. Geol. Fören. Stockholm Förh. Vol. 88, pp. 19-28.

Manuscript received, November 26, 1969. 